\title{
Biosaintifika
}

Journal of Biology \& Biology Education

http://journal.unnes.ac.id/nju/index.php/biosaintifika

\section{Analysis on the Absolute Growth Rate of Rhizophora mucronata Seed- ling in Silvicultural Pond Canals by the Influence of Initial Condi- tion and Changes of Environment Quality}

\author{
${ }^{\varpi}$ Endah Dwi Hastuti, Rini Budihastuti
}

DOI: 10.15294/biosaintifika.v8i1.5358

Department of Biology, Faculty of Science and Mathematics, Diponegoro University, Indonesia

\section{History Article}

Received 7 January 2016 Approved 23 February 2016

Published 29 March 2016

\section{Keywords:}

environment quality; growth; Rhizophora mucronata; silvofishery pond; value changes

\begin{abstract}
Mangrove seedling growth in silvofishery pond is limited to water quality dynamics while the water quality dynamically changes. This research aimed to study the changes of environmental factor condition in silvofishery pond and to analyze its impacts on the growth of mangrove seedling. Research experiment involved 18 treatment plots with mangrove Rhizophora mucronata seedling. Observed parameters included temperature, turbidity, salinity, $\mathrm{pH}, \mathrm{DO}, \mathrm{TSS}, \mathrm{BO}, \mathrm{N}$ and $\mathrm{P}$. Calculation was conducted for the deviation of each parameters. Mangrove growth parameters were including height and diameter growth while its data processing was absolute daily growth. Data analysis was conducted through regression. The result showed there were changes on environment parameters. Growth rate of $R$. mucronata showed variations on absolute daily height growth rate range of $0.215-3.333 \mathrm{~mm} /$ day (average $1.296 \pm 0.036 \mathrm{~mm} /$ day), while absolute daily diameter growth rate range was $2.15 \times 10^{-3}-0.196 \mathrm{~mm} /$ day (average $4.25 \times 10^{-2} \pm 3.59 \times 10^{-2} \mathrm{~mm} /$ day). The analysis of regression showed several parameters effectedthe growth of mangrove seedlings including temperature, temperature change, turbidty, salinity change, $\mathrm{pH}, \mathrm{pH}$ change, and DO on the growth of $R$. mucronata seedlings. This research concluded that environment parameters and its changes had significant effects on the growth of mangrove seedling.
\end{abstract}

\section{How to Cite}

Hastuti, E., \& Budihastuti, R. (2016). Analysis on the Absolute Growth Rate of Rhizophora mucronata Seedling in Silvicultural Pond Canals by the Influence of Initial Condition and Changes of Environment Quality. Biosaintifika: Journal of Biology \& Biology Education, 8(1), 56-63.

C 2016 Semarang State University $\bowtie$ Correspondence Author:

J1. Prof. Soedharto SH, Tembalang, Semarang, Central Java, Indonesia 50275

E-mail: endah_pdil@yahoo.com
p-ISSN 2085-191X e-ISSN 2338-7610 


\section{INTRODUCTION}

Degradation of mangrove ecosystem is caused by the extensivication of pond. Reforestration efforts had been conducted to recover mangrove ecosystem and its advantages (Kusaeri et al., 2015). Economic development through mangrove reforestration is expected to be achieved through its enviromental services and tourism. Development of mangrove as an ecotourism spot had been studied in several research. Thus, proper management should be formulated to avoid conflict of interest on mangrove utilization (Fahrian et al., 2015). According to Kartijono et al. (2010), mangrove ecosystem is an important habitat for various animal species which are potential for tourism

Coastal ecosystem is a threatened ecosystem both from river and sea. Acording to Dewi et al. (2014), heavy-metal contamination was detected in the Kaligarang river which caused bioaccumulation in fish tissues. The growth of mangrove seedling in silvicultural pond canal is limited to certain environmental parameters (Almulla, 2013). Meanwhile, the condition of environmental parameters continuously change as well along with the seasonal shifts (Shirodkar et al., 2012). The changes of the environment condition should influence the suitability of environmental condition to the growth of mangrove seedling (Jayatissa et al., 2008).

Generally, traditional fish ponds occupy closed system where the water circulation is only generated by the tides. It affects the pattern of water circulation and exchanges within pond canals and embankments. Especially at dry season when the sea water surface is low, static inundation probably occurs within ponds without any water exchange and circulation (Wahyudi et al., 2013). It generates the significant changes of environment parameters which finally affect the water quality and further to the growth of mangrove seedling in silvicultural pond canals.

Various environmental factors in pond canal such as temperature, turbidity, salinity, $\mathrm{pH}$, dissolved oxygen (DO) as well as nutrient concentration (organic matter $[\mathrm{OM}]$, nitrogen $[\mathrm{N}]$, phosphorus $[\mathrm{P}]$ ) are environmental parameters which always change dynamically. The changes occured in the value of environmental parameters could affect the suitability of environment to mangrove plants (Hastuti et al., 2012). Hence, the changes of environment parameters value could also provide significant influence on the growth of mangrove seedling.
Instead of environment quality, mangrove species also have various tolerance capacity to the changes of environment quality. The variation of tolerance capacity is an important factor which defines the growth rate of mangrove seedlings at similar environment conditions (Jayatissa et al., 2008). Among various available mangrove specieses, Rhizophora mucronata is a mangrove species which is mostly utilized in coastal rehabilitation programme and plantation for silvicultural ponds.

Plantation of mangrove, especially in silvicultural ponds requires consideration of the condition of environmental factors including its changes to support the plantation effectiveness. But, the information concerning the influence of environment quality and its changes on the growth of mangrove seedling are not well understood. Hence, indepth study is required to collect further information concerning the effects of environment factors and its changes on the growth of mangrove seedling in silvicultural pond. This research aimed to study the changes of environmental factors in silvicultural ponds and to analyze the influence of environment factors as well as its changes on the growth of mangrove seedling in silvicultural ponds.

\section{METHODS}

\section{Research design}

This research was conducted through field experiment in silvicultural pond at Mangunharjo Village, Tugu District, Semarang City. Observations were conducted during March up to September of 2015. Silvicultural ponds occupied in this research have embankment-canal systems in which mangrove seedlings were planted in the inlet and outlet canals of the ponds which are functioned as biofilters. The numbers of ponds utilized in this research was 18 plots occupying Rhizophora mucronata as the integrated mangrove species of silvicultural pond. Observations were conducted at each plot, including 3 mangrove stands as the samples. Observations were conducted with 3 repetitions, including early plantation period, continued with 2 following observations to monitor seedling growths.

\section{Data collection}

Data collection was conducted to monitor the environment quality factors, including water quality such as temperature, turbidity, salinity, $\mathrm{pH}, \mathrm{DO}$ and total suspended solids (TSS), and sediment quality such as OM, N and P. Data pro- 
cessing for environment quality was conducted by calculating the changes of each parameter values among the observations. While data collection of seedling growth was conducted to monitor the stand height and diameter of mangrove seedlings.

\section{Data processing and analysis}

Data processing of mangrove growth was conducted to calculate the absolute daily growth rate of mangrove seedling. Data processing of mangrove seedling growths including absolute daily height growth rate and absolute daily diameter growth rate are formulated in the following equations:

$$
\Delta h_{d}=\frac{h_{t 1}-h_{t 0}}{t}
$$

Notations:

$\Delta \mathrm{h}_{\mathrm{d}} \quad=$ absolute daily height growth rate

$\mathrm{h}_{\mathrm{t} 1} \quad=$ stand height at $\mathrm{t} 1(\mathrm{~cm})$

$\mathrm{h}_{\mathrm{t} 0} \quad=$ stand height at $\mathrm{t} 0(\mathrm{~cm})$

$\mathrm{t}=$ time period during observations (days)

$$
\Delta d_{d}=\frac{d_{t 1}-d_{t 0}}{t}
$$

Notations:

$\Delta \mathrm{d}_{\mathrm{d}} \quad=$ absolute daily diameter growth rate

$\mathrm{d}_{\mathrm{t} 1} \quad=$ stem diameter at $\mathrm{t} 1(\mathrm{~cm})$

$\mathrm{d}_{\mathrm{t} 0} \quad=$ stem diameter at $\mathrm{t} 0(\mathrm{~cm})$

$\mathrm{t}=$ time period during observations (days)

Data analysis was conducted through regression analysis. Independent variables were including environment parameters and the changes of environment parameter values, while dependent variable was the absolute growth of mangrove seedling, including absolute daily height growth rate and absolute daily diameter growth rate. Analysis of regression occupied was partial multiple regression analysis involving independent variables for environment parameters and its changes, in which each parameter was analyzed separately. Data analysis was conducted with SPSS 19 software with $90 \%$ confidence interval.

\section{RESULTS AND DISCUSSION}

The result showed there were variations of environmental quality among observations. The changes of parameters value showed various patterns among observations and plots. Proceeded observation data for respective environmental parameters value and its changes are shown in Table 1.

Data showed there were significant value differences on the observed parameters. Some parameters tended to decrease among observations indicated by negative value change, including temperature, turbidity, $\mathrm{pH}, \mathrm{DO}, \mathrm{OM}, \mathrm{N}, \mathrm{P}$ and TSS. Water salinity was the only parameter with increasing value among observations. According to the observation data presented in Table 1, the value of parameters had large range showed that there were significant variations among plots and observation periods. It indicated that there were dynamic changes on the environment quality of silvicultural pond.

Water-quality dynamics occurs continuously in mangrove ecosystem. A research conducted by Manju et al. (2012) showed that there were variations of water quality among seasons. Monsoon provided higher $\mathrm{pH}$ and DO concentration while post monsoon was lower, and pre monsoon was the lowest one. Inversely, water salinity was the lowest in terms of monsoon and the highest in pre monsoon period. Nitrate concentra-

Table 1. Value Range and Value Changes of Enviromental-Quality Parameters in Silvicultural Pond Canals [Range (Average \pm Standard Deviation)

\begin{tabular}{lll}
\hline Parameter & Observation Value & Value Changes \\
\hline Temperature $\left({ }^{\circ} \mathrm{C}\right)$ & $29.0-39.7(32.8 \pm 2.0)$ & $(-) 8.5-(+) 2.2[(-) 1.8 \pm 1.7]$ \\
Turbidity (NTU) & $80-933(346.2 \pm 218.2)$ & $(-) 772-(+) 458[(-) 14.9 \pm 254.2]$ \\
Salinity (\%o) & $19.7-32.1(26.5 \pm 4.7)$ & $(+) 5.7-(+) 14.1[9.0 \pm 1.3]$ \\
pH & $4.7-11.0(8.4 \pm 1.4)$ & $(-) 6.0-(+) 4.1[0.3 \pm 2.7]$ \\
DO (mg/1) & $2.3-10.8(6.8 \pm 1.8)$ & $(-) 6.1-(+) 5.1[(-) 0.4 \pm 2.7]$ \\
OM (\%) & $0.97-2.61(1.68 \pm 0.44)$ & $(-) 0.29-(+) 0.53[0.01 \pm 0.17]$ \\
N (\%) & $0.30-0.72(0.54 \pm 0.08)$ & $(-) 0.11-(+) 0.16[0.02 \pm 0.8]$ \\
P (ppm) & $18.37-64.87(35.83 \pm 12.09)$ & $(-) 6.95-(+) 21.76[(-) 4.01 \pm 6.00]$ \\
TSS (mg/l) & $265.4-670.9(451.0 \pm 103.9)$ & $(-) 354.4-(+) 303.1[(-) 46.9 \pm 168.3]$ \\
\hline
\end{tabular}

Notations: (-) indicates negative changes (decreasing parameter value); (+) indicates positive changes (increasing parameter value) 


\section{Endah Dwi Hastuti \& Rini Budihastuti / Biosaintifika 8 (1) (2016) 56-63}

tion was also the highest in term of monsoon and the lowest in pre monsoon as well as Phosphate. Hence, seasonal environment dynamics does not only generates the change of physical parameters, but also the chemical solubility and accumulation. Seasonal variation of water quality was also showed by Toriman et al. (2013) which showed there were differences on water temperature, salinity and turbidity between summer and monsoon season, but $\mathrm{DO}$ and $\mathrm{pH}$ did not show significant differences. Temperature, salinity and turbidity were observed higher in monsoon than summer. The changes of water quality within silvicultural pond were also affected by pond effluent from shrimp / fish culture (Shimoda et al., 2005). Mostly, pond effluent contains high concentration of nitrogen and phosphorus. The availability of mangrove stands provide purification services to the effluent produced by fish / shrimp ponds.

Data processing on the growth of mangrove seedling showed low survival rate of $R h i$ zophora mucronata seedling planted in silvicultural canals. Based on the processed data, the survival rate of Rhizophora mucronata seedling was $31.48 \%$ at first period and $38.89 \%$ at second period. It indicated that generally the condition of environment parameters in silvicultural pond canal was not suitable for the growth of mangrove seedling.

Mangrove survival is dynamic among periods. According to $\mathrm{Ha}$ et al. (2003), mangrove survival is varied by month. Depending on the location, the mortality of mangrove seedling could occur in certain months. January, February and May are suggested to provide the highest mortality rate while the recruitment only occurs from March to May (Ha et al., 2003). Continuous mortality for the whole year resulted low recruitment rate of mangrove stands. Survival rate of mangrove is affected by various factors. According to Lopez-Hoffman et al. (2007) salinity and light intensity are some factors which affect mangrove significantly.

Analysis on the absolute daily height growth rate and absolute daily diameter growth rate showed there were variations on the growth rate of $R$. mucronata seedling. Absolute daily height growth rate of $R$. mucronata ranged from $0.215-3.333 \mathrm{~mm} /$ day with average rate of 1.296 $\pm 0.036 \mathrm{~mm} /$ day while absolute daily diameter growth rate ranged from $2.15 \times 10^{-3}-0.196 \mathrm{~mm} /$ day with average rate of $4.25 \times 10^{-2} \pm 3.59 \times 10^{-2} \mathrm{~mm} /$ day. Figure 1 showed mangrove seedling of $\mathrm{R}$. mucronata planted in silvicultural pond canals.

Daily growth rate of mangrove showed significant variation both for height and diameter. Variation of mangrove growth is usually in- fluenced by environmental support. Growth of mangrove is also affected by seasonal dynamics. According to Buajan and Pumijumnong (2012), seasonal growth of $R$. mucronata is related to rain availability. In dry season, growth of mangrove is lower than in rainy season. A research conducted by $\mathrm{Ha}$ et al. (2003), also showed the temporal variation of mangrove growth. Daily mangrove seedling growth was ranged from less than $0.01 \mathrm{~cm} /$ day to nearly $0.07 \mathrm{~cm} /$ day. High growth rate was identified from April to July, while from August to March the growth rate of mangrove was lower as the period during November up to March was the peak of growth rate for mangrove. Hence, there must be seasonal stress which lead to mangrove growth inhibition. Another research conducted by deSilva and Amarasinghe (2010) showed that the growth rate of $R$. apiculata was ranged from $3.04-4.15 \mathrm{~cm} /$ month. Variation of soil sources was suggested to affect the growth rates. Dissanayake et al. (2014) observed the growth rate of $R$. mucronata ranged from $0.5-5.3 \mathrm{~cm} /$ week with rate variations among weeks. The photosynthetic capacity was suggested to be the affecting factor of growth rate variations.

Analysis on the effect of environmental parameters to the growth of mangrove seedling showed various effect patterns. The growth of mangrove seedling including absolute daily height growth rate, absolute daily diameter growth rate are affected by different environment parameters. Detailed regression analysis result is shown in Table 2.

Regression analysis showed there were significant effects of several environmental factors to the absolute growth of $R$. mucronata seedling. The value changes also showed significant effects on the growth of mangrove seedling, as well. Based on the regression analysis result presented in Table 2, the growth of $R$. mucronata seedling was affected significantly by: $\mathrm{pH}, \mathrm{pH}$ change, temperature, temperature change, turbidity, salinity change and DO. Temperature, temperature change, $\mathrm{pH}, \mathrm{pH}$ change and $\mathrm{DO}$ provided negative effects on the growth of $R$. mucronata seedling, while turbidity and salinity change provided positive effects on the growth of $R$. mucronata seedling.

The effect of temperature increase and positive change of temperature affected the growth of $R$. mucronata negatively. The negative effect of temperature on the growth of $R$. Mucronata was due to the fact that increasing temperature led to the increasing metabolism and respiration rate (Krauss et al., 2008). Disturbances caused by increasing temperature which exceeded the toler- 
Endah Dwi Hastuti \& Rini Budihastuti / Biosaintifika 8 (1) (2016) 56-63

Table 2. Effect of Environment Quality and Its Change on the Growth of Mangrove Seedling

\begin{tabular}{|c|c|c|c|c|}
\hline $\begin{array}{l}\text { Mangrove } \\
\text { Species }\end{array}$ & $\begin{array}{l}\text { Effecting Param- } \\
\text { eters } \\
\text { (environement) }\end{array}$ & $\begin{array}{l}\text { Effected } \\
\text { Parameters } \\
\text { (growth) }\end{array}$ & Equation & $\mathrm{R}^{2}$ (Sig.) \\
\hline R. mucronata & $\begin{array}{l}\text { Temp. (X1); } \\
\text { Temp_ch (X2) }\end{array}$ & $\Delta \mathrm{d}$ & $\mathrm{Y}=0,0254-0,728 \mathrm{E}-3(\mathrm{X} 1)-1,261 \mathrm{E}-3(\mathrm{X} 2)$ & $\begin{array}{l}0.130 \\
(0.087)\end{array}$ \\
\hline R. mucronata & Turbidity (X1) & $\Delta \mathrm{d}$ & $\mathrm{Y}=2,497 \mathrm{E}-3+4,761 \mathrm{E}-6(\mathrm{X} 1)$ & $\begin{array}{l}0.101 \\
(0.052)\end{array}$ \\
\hline R. mucronata & Salinity_ch (X1) & $\Delta \mathrm{d}$ & $\mathrm{Y}=-5,641 \mathrm{E}-3+1,082 \mathrm{E}-3(\mathrm{X} 1)$ & $\begin{array}{l}0.191 \\
(0.006)\end{array}$ \\
\hline R. mucronata & $\begin{array}{l}\text { pH (X1); } \\
\text { pH_ch (X2) }\end{array}$ & $\Delta \mathrm{h}$ & $Y=0,399-0,033(X 1)-0,014(X 2)$ & $\begin{array}{l}0.227 \\
(0.003)\end{array}$ \\
\hline R. mucronata & $\mathrm{DO}(\mathrm{X} 1)$ & $\Delta \mathrm{d}$ & $\mathrm{Y}=8,074 \mathrm{E}-3-0,569 \mathrm{E}-3(\mathrm{X} 1)$ & $\begin{array}{l}0.079 \\
(0.087)\end{array}$ \\
\hline
\end{tabular}

\begin{tabular}{lll}
\hline Notation: & & \\
Temp. & pH_ch & $=$ change of water $\mathrm{pH}$ \\
Temp_ch = change of water temperature & $\mathrm{DO}$ & $=$ dissolved oxygen \\
Turbidity = water turbidity & $\Delta \mathrm{h}$ & $=$ absolute daily height growth rate \\
Salinity_ch = change of water salinity & $\Delta \mathrm{d}$ & $=$ absolute daily diameter growth rate
\end{tabular}

$\mathrm{pH} \quad=$ water $\mathrm{pH}$

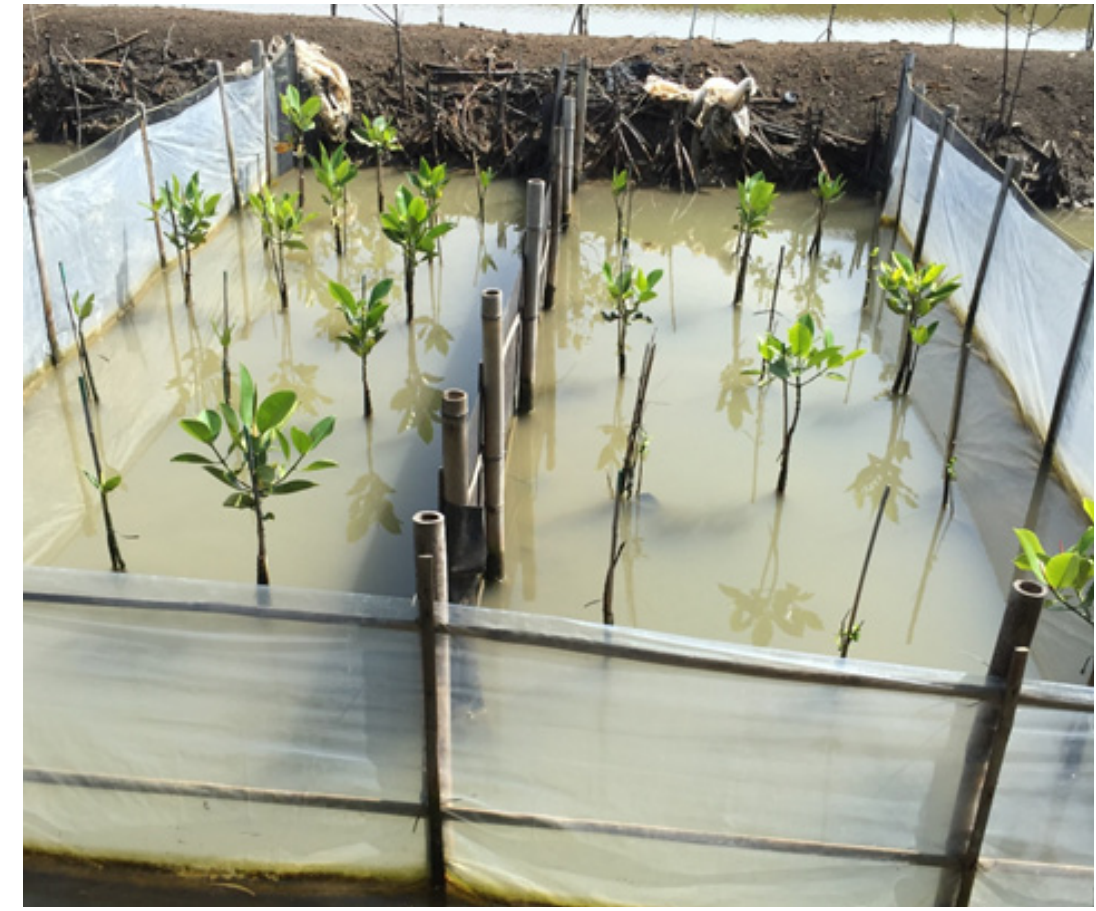

Figure 1. Mangrove $R$. mucronata seedling planted in silvicultural pond canals

ance limit included physiological processes and the damage of tissues. It also could be caused by extreme increase of temperature. Inversely, if the increase of temperature occured to the optimum range for seedling growth, it could alter the growth rate of mangrove seedlings. According to Stuart et al. (2007), mangrove is tropical vegetation whose growth is better in warm regions. According to Noor et al. (2015), both air and water temperature are important regulators for mangrove growth. Cold temperature inhibits mangrove development, while high temperature hinders tree settling. Duke et al. (1998) stated that minimum temperature for mangrove growth is $20^{\circ} \mathrm{C}$, while according to McMillan (1971) the growth of mangrove is inhibited at temperature $37^{\circ} \mathrm{C}$. Gillman et al. (2008), stated that the optimum temperature for mangrove photosynthetic is 


\section{Endah Dwi Hastuti \& Rini Budihastuti / Biosaintifika 8 (1) (2016) 56-63}

ranged from $28-32^{\circ} \mathrm{C}$, while at temperature level above $38^{\circ} \mathrm{C}$ the photosynthetic processes on mangrove leaves are halted. It implies the research results which showed temperature range from 29.0$39.7^{\circ} \mathrm{C}$. The observation results showed that the temperature of treatment plots were critical for mangrove plants. Even the average observed temperature showed the value of $32.8^{\circ} \mathrm{C}$ which is out of optimum range. Mangrove species adaptation to avoid too much water loss included wax deposition which resulted thick leaves, development of small hairs on the leaves, good regulation of stomata, and proper water storage within the leaves (Noor et al., 2015).

Increasing salinity and the value of salinity changes showed positive effect on the growth of $R$. Mucronata seedlings. Salinity is an important component for the growth of mangrove seedling (Ball et al., 2002). According to Yan et al. (2007), the optimum salinity range for the growth of mangrove seedling ranges from 5 - 30\%o. The tolerance of mangrove to the high salinity is defined by its capability on absorbing and excreting salt from its tissues (Noor et al., 1999). Mangrove could even survive at salinity level of $90 \%$ (Noor et al., 2015), but best mangrove growth is achieved when salinity fluctuations is between 5 and $75 \%$ o (Krauss et al., 2008) eventhough salinity level which is higher than $30 \%$ o has significant effect in inhibiting photosynthetic processes of mangrove (Biber, 2006). The observation results showed in salinity range between $19.7-32.1 \%$ water salinity in some treatment or period had exceeded the optimum value for mangrove growth even though the average salinity was in optimum value which meant that only a few observations had high salinity values. According to Noor et al. (2015), salinity is associated to the osmotic potential of soil solution which causes physiological drought, nutritional imbalances and specific ion toxicity. Tidal fluctuations causes the accumulation of salt concentration in the rhizosphere (Parida and Jha, 2010). Salt uptake is avoided by mangrove as an adaptation to assure water uptake from sea water to maintain its osmotic potential. Hence, water flows from higher (root) to lower (leaves) water potential (Steppe, 2011). Mangrove species have various adaptation to high salt concentration. A research conducted by Jayatissa et al. (2008) showed that growth of $R$. mucronata under low and medium salinity were not significantly different. According to Noor et al. (2015), the mechanism of Rhizophora to adapt high salinity in its habitat is caused by salt exclusion. Salt is excluded by root system of Rhizophora during uptake of water. Thus, salt intake can be avoided (Parida and
Jha, 2010). According to Buajan and Pumijumnong (2012), there was significant positive relation of salinity on vessel density of $R$. mucronata. Appropriate salinity range would provide better growth of mangrove seedling.

Water turbidity is related to the siltation rate. Proper siltation rate provides positive effect on mangrove establishment and growth of mangrove tree (Ellis et al., 2004). According to Noor et al. (2015), sedimentation within mangrove ecosystem is a mechanism to import essential nutrients. Negative effect of siltation is achieved when the siltation rate within mangrove ecosystem is higher than the erosion rate. Mangrove seedling is more vulnerable to high siltation rate. Sediment burial effects the rooting of mangrove. Sedimentation rate which exceed $1 \mathrm{~cm} /$ year would increase death ratio of mangrove trees (E1lison et al., 1998). Rhizophora seedlings are vulnerable to high siltation rate since it could lead to root damage and oxygen deficiency. High siltation rate could cover the pneumatophores existed on the roots of Rhizophora. Positive effect of turbidity on $R$. mucronata growth in this research is addressed to its effect on seedling establishment. It means the existing turbidity does not induce high siltation rate within silvicultural pond. Thampanya et al. (2002) stated that sediment burial does not affect mangrove seedling survival of $R$. mucronata at any level. Natural survival rate of $R$. mucronata is $40 \%$.

The acidity of water is related to the concentration of $\mathrm{DO}$ in the water. $\mathrm{pH}$ and $\mathrm{DO}$ have linear relation patterns in which the increaseng $\mathrm{pH}$ value is generally followed by the increasing DO concentraton of the water. The growth of mangrove is affected by soil $\mathrm{pH}$ with appropriate value less than 7.55 (Joshi and Ghose, 2003). According to Ahmed and Abdel-Hamid (2007), $R$. mucronata root system is capable of lower $\mathrm{pH}$ value after litter decomposition. Manju et al. (2012) stated that dissolved oxygen concentration affects the nitrification and sulphate reduction within the ecosystem. Since $\mathrm{pH}$ and DO are related each other, $\mathrm{pH}$ can also provide the information of nitrification rate.

\section{CONCLUSIONS}

Environmental dynamics was observed in silvicultural pond indicated by the changes environment values which influenced the growth rate of $R$. mucronata seedling. The affecting parameters were temperature, temperature change, turbidity, salinity change, $\mathrm{pH}, \mathrm{pH}$ change and $\mathrm{DO}$. Increasing value of turbidity and higher salinity 
change led to increase of mangrove growth rate, while increasing temperature, higher temperature change, increasing $\mathrm{pH}$, higher $\mathrm{pH}$ change and increasing DO led to the decrease of growth rate or mangrove seedling. It is implied that mangrove growth requires water quality maintenance, especially for temperature, salinity and $\mathrm{pH}$. A good pond water circulation management can be applied to achieve optimum water quality in silvicultural ponds.

\section{ACKNOWLEDGEMENT}

The authors acknowledge to the Director of Research and Community Services (Ditlitabmas), the General Directorate of Higher Education (Ditjen Dikti), the Ministry of Education and Culture, and the Government of Indonesia for financial support of Fundamental Research batch 2015 .

\section{REFERENCES}

Ahmed, E. A. \& Khedr, A. A. (2007). Zonation pattern of Avicennia marina and Rhizophora mucronataalong the Red Sea Coast, Egypt. World Applied Sciences Journal, 2(4), 283-288.

Almulla, L. (2013). Soil site suitability evaluation for mangrove plantation in Kuwait. World Applied Sciences Journal, 22(11), 1644-1651.

Ball, M. C. (2002). Interactive effects of salinity and irradiance on growth: implications for mangrove forest structure along salinity gradients. Trees, 16(2-3), 126-139.

Biber, P. D. (2006). Measuring the effects of salinity stress in the red mangrove, Rhizophora mangle $\mathrm{L}$. African Journal of Agricultural Research, 1(1), 1-4.

Buajan, S. \& Pumijumnong, N. (2012). Seasonal cambial activity of some mangrove trees in Inner Gulf of Thailand in dependence on climate. Songklanakarin J. Sci. Technol., 34(3), 337-344.

de Silva, K. H. W. L. \& Amarasinghe, M. D. (2010). Vegetative propagation of some selected mangrove species from Negombo estuary, Sri Lanka. Sri Lanka J. Aquat. Sci., 15, 25-38.

Dewi, N. K., Prabowo, R. \& Trimartuti, N. K. (2014). Analisis Kualitas Fisiko Kimia dan Kadar Logam Berat pad Ikan Mas (Cyprinus carpio L.) dan Ikan Nila (Oreochromis niloticus L.) di Perairan Kaligarang Semarang. Biosaintifika: Journal of Biology \& Biology Education, 6(2): 133-140.

Dissanayake, N. P., Madarasinghe, S. K., Kodikara, K. A. S., Jayatissa, L. P., Perera, A. J. D., Koedam, N. \& Dahdouh-Guebas, F. (2014). Preliminary study on the propagule dependency of Rhizophora Seedlings. Journal of the Department of Wildlife Conservation, 2(1), 141-151.

Duke, N. C., Ball, M. C. \& Ellison, J. C. (1998). Factors influencing biodiversity and distributional gradients in mangroves. Global Ecol. Biogeogr. Lett., 7(1), 27-47.

Ellis, J., Nicholls, P., Craggs, R., Hofstra, D. \& Hewitt, J. (2004). Effects of terrigenous sedimentation on mangrove physiology and associated macrobenthic communities. Marine Ecology-Progress Series, 270, 71-82.

Ellison, A. M. \& Farnsworth, E. J. (1996). Spatial and temporal variability in growth of Rhizophora mangle saplings on coral cays: Links with variation in insolation, herbivory, and local sedimentation rate. Journal of Ecology, 84, 717-731.

Fahrian, H. H., Putro, S. P. \& Muhammad, F. (2015). Potensi Ekowisata di Kawasan Mangrove, Desa Mororejo, Kabupaten Kendal. Biosaintifika: Journal of Biology \& Biology Education, 7(2), 104-111.

Gilman, E. L., Ellison, J., Duke, N. C. \& Field, C. (2008). Threats to mangroves from climate change and adaptation options: a review.Aquatic Botany, 89(2), 237-250.

Ha, H. T., Duarte, C. M., Tri, N. H., Terrados, J. \& Borum, J. (2003). Growth and population dynamics during early stages of the mangrove Kandelia candel in Halong Bay, North Viet Nam. Estuarine Coastal and Shelf Science, 58(3), 435-444.

Hastuti, E. D., Anggoro, S. \& Pribadi, R. (2012). The effect of environmental factors on the dynamic growth pattern of mangrove Avicennia marina. Journal of Coastal Development, 16(1), 57-61.

Jayatissa, L. P., Wickramasinghe,W. A. A. D. L., Dahdouh-Guebas, F. \& Huxam, M. (2008). Interspecific variations in response of mangrove seedlings to two contrasting salinities. Internat. Rev. Hydrobiol., 93(6), 700-710.

Kartijono, N. E., Rahayuningsih, M. \& Abdullah, M. 2010. Keanekaragaman Jenis Vegetasi dan Profil Habitat Burung di Hutan Mangrove Pulau Nyamuk Taman Nasional Karimunjawa. Biosaintifika: Journal of Biology \& Biology Education, 2(1): 27-39.

Kraus, K.W., Lovelock, C. E., McKee, K. L., LopezHoffman, L., Ewe, S. M. L. \& Sousa, W. P. (2008). Environmental drivers in mangrove establishment and early development: a review. Aquatic Botany, 89(2), 105-127.

Kusaeri, Putro, S. P. \& Wasiq, J. (2015). Potensi Sumberdaya Alam Hayati Kawasan Mangrove Pasar Banggi Kabupaten Rembang sebagai Obyek Ekowisata. Biosaintifika: Journal of Biology \& Biology Education, 7(2), 120-127.

Lopez-Hoffman, L., Anten, N. P. R., Martinez-Ramos, M. \& Ackerly, D. D. (2007). Salinity and light interactively affect neotropical mangrove seedlings at the leaf and whole plant levels. Oceologia, 150(4), 545-556.

Manju, M. N., Resmi, P., Kumar, T. R. G., Kumar, C. S. R., Rahul, R., Joseph, M. M. \& Chandramohanakumar, N. (2012). Assessment of water quality parameters in mangrove ecosystem along Kerala Coast: a statistical approach. Int. 
J. Environ. Res., 6(4), 893-902.

McMillan, C. (1971). Environmental factors affecting seedling establishment of the black mangrove on the Central Texas Coast. Ecology, 52, 927930.

Noor, T., Batool, N., Mazhar, R. \& Ilyas, N. (2015). Effectsof siltation, temperature and salinity on mangrove plants. European Academic Research, 2(11), 14172-14179.

Noor, Y. R., Khazali, M. \& Suryadiputra, I. N. N. (1999). Panduan Pengenalan Mangrove di Indonesia. Bogor: Wetlends International- Indonesia Programe.

Parida, A. K. \& Jha, B. (2010). Salt tolerance mechanisms in mangroves: a review. Trees-Structure and Function, 24(2), 199-217.

Shimoda, T., Srithong, C. \& Aryuthaka, C. 2005. Attempt at purification of effluent and sediment in shrimp aquaculture ponds using mangrove trees. JARQ, 39(2), 139-145.

Shirodkar, P. V., Deepthi, M., Vethamony, P., Mesquita, A. M., Pradhan, U. K., Babu, M. T., Verlecar, X. N. \& Haldankar, S. R. (2012). Tide dependend seasonal changes in water quality and assimilative capacity of anthropogenically influenced Mormugao Harbour water. Indian Journal of Geo-Marine Sciences, 41(4), 314-330.
Steppe, K., Dzikiti, S., Lemeur, R. \& Milford, J. R. (2006). Stomatal oscillations in orange trees under natural climatic conditions. Annals of Botany, 97(5), 831-835.

Stuart, S. A., Choat, B., Martin, K. C., Holbrook, N. M. \& Ball, M. C. (2007). The role of freezing in setting the latitudinal limits of mangrove forests. New Phytol., 173(3), 576-583.

Thampanya, U., Vermaat, J. E. \& Terrados, J. (2002). The effect of increasing sediment accretion on the seedlings of three common Thai mangrove species. Aquatic Botany, 74(4), 315-325.

Toriman, M. E., Arfan, A. \& Yusop Z. (2013). Assessment of mangrove water quality by multivariate statistical analysis in Suppa Coast, South Sulawesi, Indonesia. World Applied Sciences Journal, 28(9), 1301-1310.

Wahyudi, A. I., Pangerang, U. K. \& Mustafa, A. (2013). Evaluasi kesesuaian lingkungan pada kawasan tambak di Kecamatan Kolono Kabupaten Konawe Selatan. Jurnal Mina Laut Indonesia, 2(6), 1-13.

Yan, Z., Wang, W. \& Tang, D. (2007). Effect of different time of salt stress on growth and some physiological processes of Avicennia marina seedlings. Marine Biology, 152(3), 581-587. 